\title{
Uji Toksisitas Akut Herbisida Sintetik Ipa Glifosat Terhadap Mortalitas Benih Ikan Lele Sangkuriang (Clariasgariepinus)
}

\author{
Ita Emilia $^{1 *}$, Andi Arif Setiawan ${ }^{2}$, Monica Dwi Mutiara $^{3}$ \\ *e-mail: itaemilia742@gmail.com \\ ${ }^{1,3}$ Program Studi Biologi, ${ }^{2}$ Program Studi Fisika \\ Fakultas Sains dan Teknologi \\ Universitas PGRI Palembang
}

\begin{abstract}
The acute research toxicity test of Ipa Glyphosate herbicide toward mortality of sangkuriang catfish seeds (Clarias gariepinus) as a non target organism. The aim is to decide the concentrate of Ipa Glyphosate herbice that caused 50\% mortality of sample (LC50) and the middle time mortality of sample (LT50. The toxicity test had done on March until May 2019 at Integrated Laboratory of PGRI Palembang University. Toxicity test of Ipa Glyphosate herbicide toward mortality of sangkuriang catsfish seeds used bioassay method for 96 hours. Concentrate that used: 29,3\%, 34,2\%, 39,7\%, 45,6\%, 52,1\%, and $59,3 \%$. The result of this research was got LC50 24 hours was $68,346 \%, 48$ hours was $41,094 \%, 72$ hours was 34,287\%, 96 hours was $29,957 \%$, and the result of LT50 for $29,3 \%$ concentrate was 79 hours, LT50 for $34,2 \%$ concentrate was got 76 hours, LT50 for $39,7 \%$ concentrate was got 68 hours, LT50 for $45,6 \%$ concentrate was got 42 hours, LT50 for $52,1 \%$ concentrate was got 41 hours, and LT50 59,3\% concentrate was got 32 hours. Getting lower the concentrate of Ipa Glyphosate herbicide that used, it means more longer time needed to killing the sample.
\end{abstract}

Keywords : toxicity, ipa glyphosate, mortality, catfish seeds

\begin{abstract}
ABSTRAK
Penelitian uji toksisitas akut herbisida sintetik berbahan aktif Ipa Glifosat terhadap mortalitas benih ikan lele sangkuriang (Clarias gariepinus) sebagai organisme non target bertujuan untuk menentukan konsentrasi herbisida berbahan aktif Ipa Glifosat yang menyebabkan kematian 50\% hewan uji (LC50) dan waktu tengahan (LT50) kematian hewan uji. Uji toksisitas menggunakan metode bioassay dengan waktu uji selama 96 jam. Konsentrasi yang digunakan 29,3\%, 34,2\%, 39,7\%, 45,6\%, 52,1\%, 59,3\%. Hasil penelititan didapatkan LC50 24 jam sebesar 68,346\%, LC50 48 jam sebesar 41,094\%, LC50 72 jam sebesar 34,287\%, dan LC50 96 jam sebesar 29,957\%, sedangkan nilai LT50 untuk konsentrasi 29,3\% sebesar 79 jam, LT50 konsentrasi 34,2\% didapatkan 76 jam, LT50 untuk konsentrasi 39,7\% didapatkan 68 jam, LT50 untuk konsentrasi 45,6\% sebesar 42 jam, LT50 untuk konsentrasi $52,1 \%$ sebesar 41 jam, dan LT50 untuk konsentrasi $59,3 \%$ sebesar 32 jam. Semakin rendah konsentrasi herbisida sintetik berbahan aktif Ipa Glifosat maka semakin lama pula waktu yang diperlukan untuk mematikan hewan uji tersebut.
\end{abstract}

Kata kunci : toksisitas, ipa glifosat, mortalitas, benih ikan Lele 


\section{PENDAHULUAN}

Herbisida merupakan salah satu senyawa kimia yang digunakan untuk menghambat pertumbuhan atau mematikan tumbuhan. Herbisida dapat bersifat racun bagi gulma atau tumbuhan pengganggu juga terhadap tanaman. Gulma diberantas dengan cara herbisida mengubah pengaruh bahan kimia di dalam jaringan gulma, yang dapat mematikan jaringan itu atau merusak suatu sistem fisiologis yang dibutuhkan untuk hidup atau pertumbuhan, pernafasan, fotosintesis, pembelahan sel, dan pemanjangan sel terganggu (Riadi, 2011). Herbisida yang digunakan, hanya sebagian kecil yang diaplikasikan benar- benar mencapai gulma target, dan sebagian besar sisanya terlepas ke lingkungan mengakibatkan pencemaran dan berpotensi mematikan pada spesies non target lainnya yang mempunyai peranan penting di lingkungan, misalnya alga (Prado et al., 2009).

Herbisida sintetik yang bersifat non spesifik tersebut contohnya glifosat yang merupakan salah satu contoh herbisida yang digunakan setelah tumbuh dan berkarakter sistemik (Rolando et al., 2017). Gulma yang menjadi sasaran mengalami pertumbuhan setelah diberikan herbisida, yang berbahan aktif IPA Glifosat (Umiyati et al., 2018). Gulma golongan rumput menjadi daun lebar, setelah diaplikasikan dengan herbisida isopropilamina glifosat, dan mengalami perubahan komposisi gulma, yaitu pada 4 -12 MSA (Oktavia et al., 2019) Glifosat sebagai herbisida ini sudah umum digunakan, dikarenakan mempunyai spektrum pengendalian luas dan bersifat non selektif dalam mengendalikan gulma. Kondisi ini cocok digunakan untuk mengatasi berbagai gulma. Glifosat bekerja dengan menghambat sintesis asam amino aromatik melalui penghambatan enzim EPSPS (5- enolpyruvylshikimate-3phosphate synthase) (Tomlin, 2010).

Kematian ikan akibat penggunaan herbisida disebabkan masuknya herbisida melalui insang yang merupakan alat pertukaran gas, selanjutnya akan masuk ke saluran darah, dan mengganggu kerja enzim pengatur saraf, hal ini mengakibatkan saraf bekerja tanpa dapat dikendalikan dan menyebabkan kematian pada ikan (Yudhi, 2014).

Ikan yang hidup di air tawar yang bertulang sejati salah satunya yaitu ikan lele. Ikan ini di kelompokan dalam ordo siluriformes. Ciri morfologinya tubuh yang licin, pipih memanjang dan memiliki sungut yang menyembul dari daerah sekitar mulut. Nama ilmiahnya Clarias sp. (bahasa Yunani "chlaros"), berarti "kuat dan lincah", Istilah Inggris disebut dengan catfish, mudfish dan walking catfish (Hilwa, 2004).

Uji toksisitas dilakukan agar dapat mengetahui efek letal suatu senyawa toksik yaitu untuk mengetahui kematian biota uji akibat konsentrasi senyawa kimia tertentu yang terkandung dalam suatu limbah, dicatat sebagai median letal concentration $\left(\mathrm{LC}_{50}\right)$ (AlAttar, 2005). Uji toksisitas bertujuan memperkirakan dampak dari pajanan zat kimia / bahan asing, dikarenakan semuanya berdampak jelek bagi makhluk hidup dan semua zat asing tersebut memiliki tingkat toksisitas yang berbeda (Lu, 2006). Uji toksisitas dengan menggunakan organisme memberikan dampak penting terhadap perkembangan manajemen budi daya perikanan (Le et al., 2005). Penelitian ini mengunakan penerapan uji toksisitas akut lethal concentration 50-96 hours 
(LC $\left.\mathrm{L}_{50}-96 \mathrm{~h}\right)$ yang mengacu pada USEPA (2002).

Uraian tersebut di atas yang melatar belakangi penulis tertarik untuk lele sangkuriang sebagai organisme non target. Ikan lele ini dipilih sebagai objek pengamatan dalam penelitian karena dianggap memiliki daya hidup yang kuat, dapat hidup di tempat dengan jumlah air yang sedikit dengan keadaan air keruh.

\section{BAHAN DAN METODE}

Bahan-bahan yang digunakan yaitu air tawar, benih ikan lele dengan umur \pm 20 hari, jenis ikan lele sangkuriang dengan ukuran benih ikan lele yang relatif seragam, herbisida berbahan aktif ipa glifosat 486 gr/liter.

Metode yang dilakukan yaitu uji hayati (Bioassay) dengan medium static dengan dua tahapan. Tahap 1 uji pendahuluan, bertujuan mendapatkan kisaran konsentrasi yang akan digunakan untuk uji tahap 2 berupa uji toksisitas. Uji toksisitas ini bertujuan menentukan jumlah dan waktu kematian akibat konsentrasi herbisida sintetik yang akan diujikan selama 96 jam, sehingga LC $_{50}$ dan $\mathrm{LT}_{50}$ dapat diketahui.

\section{HASIL DAN PEMBAHASAN}

Setelah dilakukan uji pendahuluan Nilai LC $_{50} 24$ jam sebesar 68,346\% dengan interval kepercayaan 95\%, melakukan penelitian uji toksisitas akut herbisida sintetik berbahan aktif ipa glifosat terhadap mortalitas benih ikan

dengan batas atas $90,724 \%$ dan batas bawah 59,980\% yang berarti bahwa pemberian herbisida berbahan aktif ipa glifosat dengan konsentrasi $68,346 \%$ dapat menyebabkan 50\% kematian benih ikan lele.

Nilai LC $_{50} \quad 48$ jam sebesar $41,094 \%$ dengan interval kepercayaan 95\% dengan batas atas $44,681 \%$ dan batas bawah $37,364 \%$, s udah menyebabkan kematian $50 \%$ benih ikan lele dalam waktu 48 jam. Nilai LC $_{50} 72$ jam sebesar $34,287 \%$ dengan interval kepercayaan 95\%,dengan batas atas $37,150 \%$ dan batas bawah 30,540 \%, menunjukkan kematian $50 \%$ benih ikan lele dalam waktu 72 jam.

Nilai LC $_{50}$ pada waktu 96 jam sebesar 29,957\% dengan interval kepercayaan $95 \%$, dengan batas atas $32,685 \%$ dan batas bawah 25,568\%, sudah menyebabkan kematian $50 \%$ benih ikan lele dalam waktu 96 jam.

Nilai LC50 selama 24, 48, 72, dan 96 jam dari kisaran konsentrasi herbisida berbahan aktif ipa glifosat yang telah ditentukan ini menunjukkan bahwa semakin lama waktu perlakuan maka semakin kecil nilai konsentrasi herbisida sintetik yang dapat menyebabkan kematian 50\% hewan uji.

Tabel 1. Hasil uji toksisitas akut yang telah dilakukan selama 96 jam

\begin{tabular}{cc}
\hline Waktu perlakuan (Jam) & LC50 (\%) \\
\hline 24 & 68,346 \\
48 & 41,094 \\
72 & 34,287 \\
96 & 29,957 \\
\hline
\end{tabular}




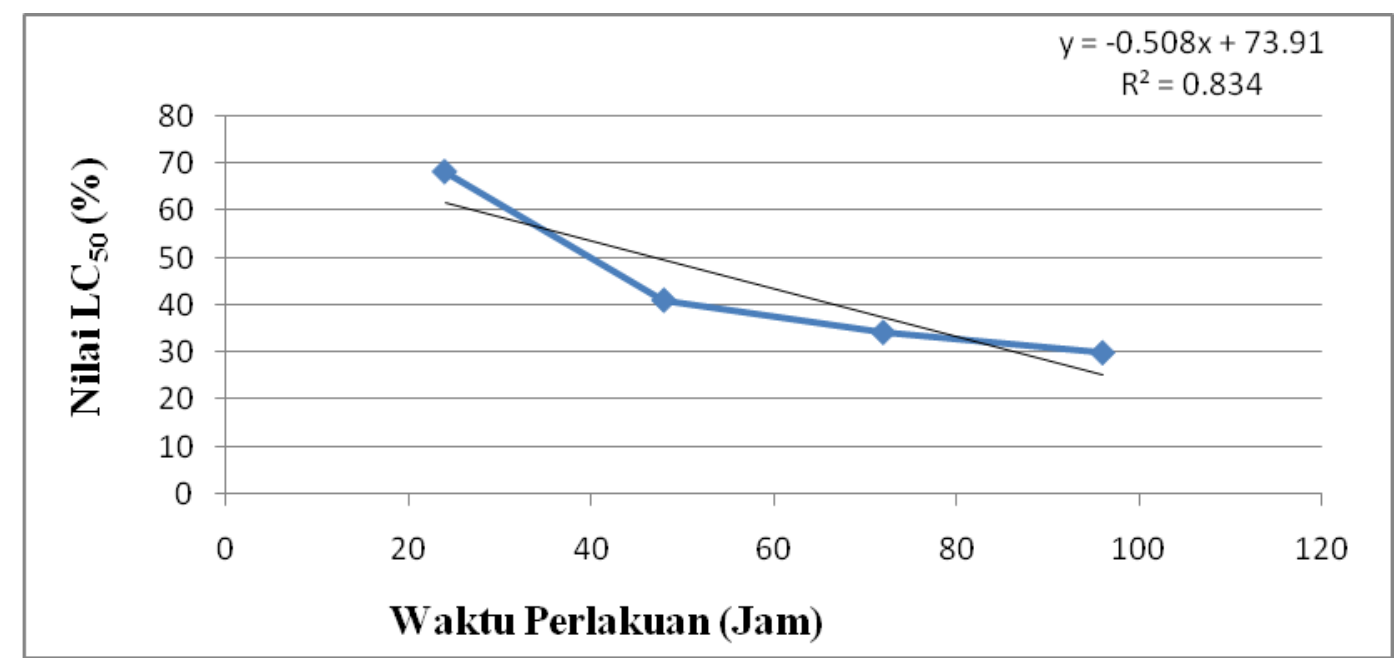

Gambar 1: Grafik memperlihatkan nilai konsentrasi yang menyebabkan kematian $50 \%$ ( $\left.\mathrm{LC}_{50}\right)$ benih ikan lele sangkuriang (Clarias gariepinus), pada waktu 24 jam, 48 jam, 72 jam, dan 96 jam.

Grafik pada Gambar 1 menunjukkan hubungan antara konsentrasi larutan uji terhadap kematian $50 \%$ hewan uji $\left(\mathrm{LC}_{50}\right)$ dengan waktu aplikasi 24 jam, 48 jam, 72 jam dan 96 jam yang menunjukkan persamaan regresi $\mathrm{Y}=-0,5082 \mathrm{x}+73,915$ dengan nilai $\mathrm{R}^{2}=0,8345$. Nilai ini menunjukkan bahwa herbisida berbahan aktif ipa glifosat dengan waktu 96 jam dapat menyebabkan kematian 50\% hewan uji benih ikan lele sangkuriang (Clariasgariepinus) dengan konsentrasi paling rendah 29,957\%. Dan pada waktu perlakuan yang lebih singkat yaitu 24 jam menunjukan nilai konsentrasi tertinggi $68,346 \%$ untuk dapat menyebabkan kematian hewan uji. Hal ini sejalan dengan pendapat Hiola dan Bahri (2010), bahwa toksisitas suatu bahan tergolong efektif jika mampu membunuh hingga 50\% atau lebih dari populasi hewan uji. Uji toksisitas juga bertujuan untuk mengetahui nilai $\mathrm{LT}_{50}$.
Herbisida sintetik yang telah diaplikasikan dengan hewan uji mempunyai kemampuan untuk membunuh benih ikan lele, karena di dalam herbisida sintetik berbahan aktif ipa glifosat terdapat kandungan senyawa kimia terpenting dalam herbisida yaitu senyawa glifosat [N(phosphonomethyl)glysin] merupakan salah satu herbisida dari golongan phosphono amino acid yang bersifat non selektif (Taufiq, 2003).

Herbisida mempunyai cara kerja yang menyebabkan kematian pada ikan yaitu masuknya herbisida melalui insang yang merupakan alat pertukaran gas, selanjutnya akan masuk ke saluran darah, dan mengganggu kerja enzim pengatur saraf. Hal ini mengakibatkan saraf bekerja tanpa dapat dikendalikan menyebabkan kematian pada ikan (Yudhi, 2014). 
Tabel 2. Nilai $\mathrm{LT}_{50}$ yang menyebabkan kematian $50 \%$ hewan uji

\begin{tabular}{cc}
\hline Konsentrasi $(\%)$ & LT $_{50}(\mathrm{Jam})$ \\
\hline 29,3 & 79 \\
34,2 & 76 \\
39,7 & 68 \\
45,6 & 42 \\
52,1 & 41 \\
59,3 & 32 \\
\hline
\end{tabular}

Nilai $\mathrm{LT}_{50}$ yang didapatkan pada konsentrasi 29,3\% sebesar 79 jam hasil ini menujukkan herbisida sintetik berbahan aktif ipa glifosat yang telah diaplikasikan terhadap benih ikan lele dapat menyebabkan kematian 50\% hewan uji pada waktu tersebut, konsentrasi 29,3\% membutuhkan waktu yang lebih lama untuk membunuh 50\% hewan uji.

Nilai LT $_{50}$ yang didapatkan pada konsentrasi 34,2\% sebesar 76 jam sudah dapat menyebabkan kematian 50\% hewan uji, ini juga menunjukkan bahwa semakin tinggi konsentrasi herbisida berbahan aktif ipa glifosat yang diaplikasikan terhadap hewan uji, maka semakin cepat waktu kematian hewan uji tersebut.

Nilai $\mathrm{LT}_{50}$ yang didapatkan pada konsentrasi 39,7\% sebesar 68 jam menunjukkan bahwa konsentrasi ini sudah dapat membunuh 50\% hewan uji. Nilai $\mathrm{LT}_{50}$ yang didapatkan pada konsentrasi $45,6 \%$ sebesar 42 jam sudah dapat membunuh $50 \%$ hewan uji. Nilai LT $_{50}$ yang didapatkan pada konsentrasi $52,1 \%$ sebesar 41 jam juga sudah dapat membunuh 50\% hewan uji tersebut. Konsentrasi tertinggi $59,3 \%$ memiliki nilai $\mathrm{LT}_{50}$ sebesar 32 jam, pada konsentrasi ini dapat membunuh 50\% hewan uji dengan waktu yang paling cepat dibandingkan konsentrasi- konsentrasi lainnya. Nilai $\mathrm{LT}_{50}$ yang didapatkan dari uji toksisitas herbisida sintetik berbahan aktif ipa glifosat ini menunjukan bahwa konsentrasi terendah memiliki nilai waktu tertinggi yaitu pada konsentrasi 29,3\% dengan nilai waktu 79 jam, sedangkan konsentrasi tertinggi memiliki nilai waktu yang lebih rendah yaitu pada konsentrasi 59,3\% dengan nilai waktu 32 jam.

Hewan uji yang awalnya memiliki daya tahan tubuh kuat masih mampu beradaptasi pada 8 jam pertama, lama-kelamaan hewan uji akan melemah karena didalam tubuhnya herbisida ipa glifosat ini mulai bereaksi dan terakumulasi kemudian benih ikan lele akan mengalami gangguan fungsi organ tubuh sehingga hewan uji tersebut akan mati.

Konsentrasi larutan uji yang tertinggi tidak membutuhkan waktu yang lama untuk menyebabkan kematian 50\% hewan uji $\left(\mathrm{LT}_{50}\right)$. Ini dimungkinkan karena hewan uji yang diaplikasikan pada konsentrasi tertinggi 59,3\% terpapar paling banyak kandungan herbisida sintetik berbahan aktif ipa glifosat di dalam larutan uji.

Nilai LT $_{50}$ yang didapatkan dari uji toksisitas herbisida berbahan aktif ipa glifosat terhadap benih ikan lele digambarkan pada Grafik 2. 


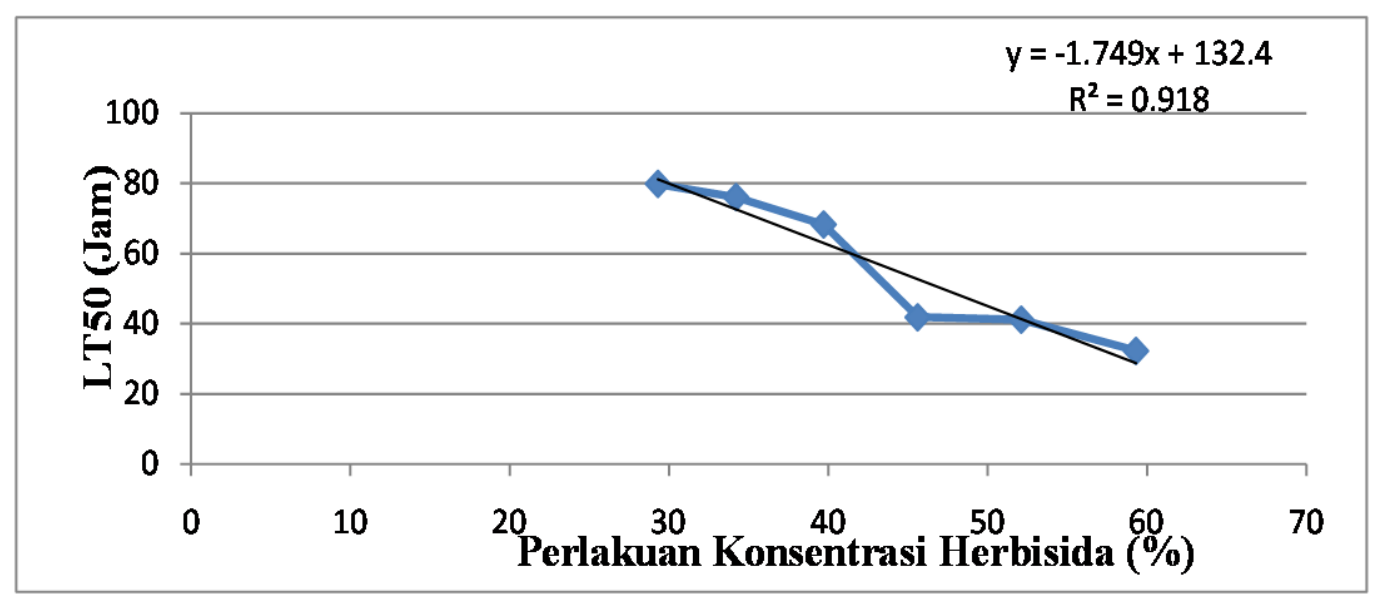

Gambar 2 : Grafik pengaruh herbisida berbahan aktif ipa glifosat terhadap waktu kematian $50 \%\left(\mathrm{LT}_{50}\right)$ benih ikan lele sangkuriang (Clariasgariepinus)dengan konsentrasi $29,3 \%, 34,2 \%, 39,7 \%, 45,6 \%, 52,1 \%$ dan 59,3\%.

Gambar 2 menunjukkan hubungan antara pengaruh pemberian herbisida sintetik terhadap waktu kematian $50 \%$ hewan uji $\left(\mathrm{LT}_{50}\right)$ dengan persamaan regresi $\mathrm{Y}=-1,7495 \mathrm{x}$ $+123,48, \quad \mathrm{R}^{2} \quad=0,9184$. Hal ini menunjukkan hubungan yang sangat kuat antara pengaruh pemberian herbisida sintetik dengan waktu kematian 50\% hewan uji $\left(\mathrm{LT}_{50}\right)$. Pada Gambar 2 menunjukkan bahwa dengan konsentrasi 29,3\% diperlukan waktu yang lebih lama untuk membunuh $50 \%$ hewan uji (LT 50$)$, dibandingkan dengan konsentrasi $34,2 \%, 39,7 \%, 45,6 \%, 52,1 \%$ dan $59,3 \%$.
Hal ini menjelaskan bahwa sintetik yang diberikan kepada hewan uji, maka semakin lama waktu yang diperlukan untuk membunuh 50\% hewan uji $\left(\mathrm{LT}_{50}\right)$.

Berdasarkan

$\mathrm{u} \mathrm{j} \mathrm{i}$

toksisitas yang telah

dilakukan disimpulkan bahwa senyawa ipa glifosat merupakan senyawa yang sangat toksik terhadap benih ikan lele sangkuriang, dikarenakan nilai $\mathrm{LC}_{50}$ selama 96 jam menunjukkan <1 mg/l. Hal ini sejalan dengan pendapat APEA dan ERDC (1994) dalam Rossiana dkk. (2006) yang menyatakan tingkatan toksisitas pada tabel 3 .

Tabel 3. Kriteria toksisitas

\begin{tabular}{ccc}
\hline Urutan & Ketegori & $\mathrm{LC}_{50}(\mathrm{mg} / \mathrm{l})$ \\
\hline 1 & Tidak toksik & $>100000$ \\
2 & Hampir tidak toksik & $10000-100000$ \\
3 & Rendah & $1000-10000$ \\
4 & Sedang & $100-1000$ \\
5 & Toksik & $1-100$ \\
6 & Sangat toksik & $<1$ \\
\hline
\end{tabular}

Benih ikan lele yang mati karena herbisida sintetik berbahan aktif ipa glifosat ini menunjukan ciri morfologi dan ciri prilaku, ciri ini timbul karena faktor penyebab kematian hewan uji akibat terpapar senyawa kimia herbisida sintetik, senyawa ini bersifat non spesifik yang artinya senyawa dapat memberikan dampak kepada semua jenis mahluk hidup yang terpapar atau terkontaminasi 
oleh senyawa ini, jika diaplikasikan terhadap tumbuhan dapat menyebabkan kematian karena menyerang enzim 5enoylpyruvate shikimic acid-3-phosphate synthase (EPSP synthase) yang terdapat di kloroplas yang merupakan enzim penting pada tumbuhan untuk berperan dalam biosintesis asam amino aromatik seperti triptopan, fenilalanin, dan tirosinyang penting bagi kelangsungan hidup tanaman (Tomlin, 2010).

Berikut ini dampak yang ditimbulkan dari senyawa herbisida sintetik berbahan aktif ipa glifosat apabila terkontaminasi pada hewan uji benih ikan lele sangkuriang berdasarkan pengamatan peneliti, ciri perilaku benih ikan lele yang terkontaminasi herbisida sintetik adalah sebagai berikut :

1. Nafsu makan ikan berkurang, pada tahap aklimatisasi ikan memiliki nafsu makan yang kuat, pakan yang diberikan pada waktu-waktu tertentu mudah dan cepat sekali habis, pada hewan uji kontrol saat pemberian pakan hewan uji masih merespon cepat pakan dan bergerak aktif, tapi pada hewan uji yang diberi perlakuan hewan lebih bergerak pasif dan tidak terlalu merespon pakan yang diberi bahkan ikan lebih sering tidak memakannya.

2. Keseimbangan ikan terganggu, berenang tidak normal ikan berenang terbalik dan kadang menyamping, ikan tidak berenang aktif, lebih sering diam menggantung di permukaan air dengan posisi kepala sedikit keluar dari air, atau diam di dasar air dan akibatnya ikan lebih mudah di tangkap.

\section{KESIMPULAN}

Dari hasi penelitian yang telah dilakukan dapat diambil kesimpulan sebagai berikut :

1. Konsentrasi herbisida berbahan aktif ipa glifosat dapat menyebabkan kematian $50 \%$ benih ikan lele sangkuriang (Clarias gariepinus) dengan waktu aplikasi $\mathrm{LC}_{50} 24$ jam sebesar 68,346\%, 48 jam 41,094\%, 72 jam 34,287\%, dan 96 jam sebesar $29,957 \%$ hal ini menjelaskan bahwa semakin lama waktu perlakuan maka semakin kecil nilai konsentrasi yang menyebabkan kematian 50\% hewan uji $\left(\mathrm{LC}_{50}\right)$.

2. Waktu tengahan (LT $\left.{ }_{50}\right)$ yang diperlukan herbisida berbahan aktif ipa glifosat untuk membunuh hewan uji, yaitu konsentrasi 29,3\% selama 79 jam, 34,2\% selama 76 jam, 39,7\% selama 68 jam, 45,6\% selama 42 jam, 52,1\% selama 41 jam, dan $59,3 \%$ selama 32 jam hal ini menjelaskan semakin rendah konsentrasi herbisida sintetik yang diberikan kepada hewan uji, maka semakin lama waktu yang diperlukan untuk membunuh 50\% hewan uji (LT50).

3. Herbisida sintetik ipa glifosat menyebabkan pengaruh negatif terhadap hewan uji yang terkontaminasi karena bersifat sangat toksik, hewan uji mengalami perubahan yang sangat terlihat pada prilaku dan morfologinya.

\section{DAFTAR PUSTAKA}

Al-Attar AM. 2005. Changes in Haematological Parameters of the Fish, Oreochromis niloticus Treated with Sublethal Concentration of Cadmium. Pakistan Journal of Biological Sciences. 8(3): 421-424. 
Hilwa, Z. 2004. Karakterisasi Genotip Ikan Lele Mutiara dengan Metode PCR-RFLP ADN Mitokondria. Institut Pertanian Bogor.

Hiola, S.F., dan Bahri, A. 2010. Uji Toksisitas Ekstrak Daun Ketepeng Cina (Cassia alata L.) pada Keong Mas (Pomacea canaliculata L.). Bionature. 11(2): 115-119.

Le QD, Nguyen MC, Nguyen TH, Nguyen DC. 2005. Acute Toxicity Test to Determine the Effects of Copper, Zinc and Cyanide on Cobia (Rachycentron canadium) Resources in North Vietnam. Australian Journal of Ecotoxicology. 11: 163-166.

Lu, F.C., 2006. Toksikologi Dasar (Asas Organ Sasaran dan Penilaian Resiko). Edisi II. Penerjemah: E. Nugroho, Z.S. Bustaminan Z., Parmansjah. Universitas Indonesia, Jakarta.

Oktavia, Kurnia., Hidayat, Pujisiswato., Rusdi, Evizal., Herry, Susanto. 2019. Pengaruh Aplikasi Glifosat terhadap Efikasi dan Komposisi Gulma Pertanaman Kelapa Sawit Tanaman Menghasilkan Muda. Jurnal Agro Industri Perkebunan. 7(1): 1-9.

Prado, R., Rioboo, C., Herrero, C., Cid, A. 2009. The Herbicide Paraquatinduces Alterations in The Elemental and Biochemical Compositionof Non-Target Microalgal Species. Chemosphere. 76: 1440-1444.

Riadi, M. 2011. Mata Kuliah: Herbisida dan Aplikasinya. Bahan Ajar. Universitas Hasanuddin. $138 \mathrm{hlm}$.

Rolando, C.A., B.R, Baillie., D.G, Thompson., and K.M, Little. 2017. The Risks Associated With Glyphosate-Based Herbicide Use in
Planted Forests. Forest Journal 8 (208):1-25.

Rossiana, N., Supriatun, T., dan Dhahiyat, Y. 2006.

Fitoremediasi Limbah Cair

Dengan Eceng Gondok (Eichhornia crassipes (Mart) Solms) dan Limbah Minyak Bumi Dengan Sengon (Paracerianthes falcataria L. Nielsen) Bermikoriza. Laporan Penelitian. Universitas Padjajaran. Bandung.

Taufiq, D. 2003. Studi Efektivitas glifosat $480 \mathrm{gl}$ pada Beberapa Taraf Dosis terhadap Pengendalian Gulma Alang-alang (Imperatacy lindrica (L.) Beauv.). Skripsi. Bogor (ID): Jurusan Budidaya Pertanian, Fakultas Pertanian. Institut Pertanian Bogor.

Tomlin, C.D.S. 2010. A World Compedium The Pesticide Manual. Fifteenth ed. British Crop Protection Council. English. 1606 hlm.

Umiyati, Uum., Deden., Dedi, Widayat., Ammar, Muhtadi. 2018. Uji Sifat Campuran Herbisida Berbahan Aktif IPA Glifosat dan 2,4 D Amina Terhadap Beberapa Jenis Gulma. LOGIKA. XXII(1): 44-49.

USEPA (United States Environmental Protection Agency). 2002. Method for Measuring the Acute Toxicity of Effluents and Receiving Waters to Freshwater and Marine Organism. Fifth Edition. EPA-821-R-02012.Office of Water (43035). Washington DC.

Yudhi, N.L. 2014. Uji Toksisitas Akut Insektisida Diazinon Dan Klorpirifos Terhadap Biota Uji Ikan Guppy (Poecilia Stratiotes) Dan Tumbuhan Kayu Apu (Pistia Stratiotes). Tugas Akhir Institut Teknologi Sepuluh Nopember. Surabaya. 